\title{
Development of Human Umbilical Vessels in The Second Trimester of Pregnancy: Histological, Immunohistochemical and Morphometric Study
}

\section{Original Article}

\author{
Nagwa Ebrahim EI-Nefiawy \\ Department of Human Anatomy and Embryology, Faculty of Medicine, Ain shams University, \\ Cairo, Egypt.
}

\begin{abstract}
Introduction: There are many publications describing structure of full term umbilical vessels, however, few studies in early gestation.

Aim: To elucidate changes in microstructure of developing umbilical vessels in the second trimester of pregnancy.

Material and Methods: Twelve specimens of human umbilical cords were obtained from legal termination of uncomplicated pregnancies at gestational weeks 13,16, and 20. Two centimeter segments of the cords were cut near the placenta. Specimens were processed for paraffin blocks, sectioned, and stained with haematoxylin \& eosin, Masson Trichrome, Orcein, and Periodic Acid Schiff. Immunohistochemistry for alpha smooth muscle actin \& laminin antibodies was performed. Morphometry and image analysis for vascular wall thickness \& diameter of lumen, and diameter of umbilical cord were done.

Results: Umbilical cord sections revealed two arteries (UA) and one vein (UV) embedded in Wharton's jelly and covered with amniotic epithelium formed of flat then cuboidal epithelium. Umbilical vessels composed of inner intima and outer media. Endothelium demonstrated areas of damage and adhesion of inflammatory cells. Internal elastic lamina was thin, interrupted initially, double layered, and well-developed finally. Smooth muscle cells (SMCs) migrated from vascular lumen or from media by a process of mesenchymal-endothelial transition to replace injured endothelium. The media was composed of immature SMCs initially (thin (morphometry), non-contractile, non-secretory as proved by different stains and collagen content. Wharton's jelly spindle shaped mesenchymal cells close to vessels revealed positive staining for alpha smooth muscle actin and contributed to the media to compensate for SMC migration. UAs showed thicker wall, narrower lumen than veins and cord diameter increased significantly at the 20 week.

Conclusion: Development of umbilical vessels was the result of a continuous remodeling process initiated by secreted endothelial factors from damaged endothelium that influenced; SMCs of media, stem cells of cord blood and Wharton's jelly simulating early events of atherosclerosis.
\end{abstract}

Keywords: Alpha smooth muscle actin, human, histology, laminin, morphometry, second trimester pregnancy, umbilical artery, umbilical vein, vascular remodeling

Revised: 26 December 2016, Accepted: 06 July 2017

Corresponding Author: Nagwa Ebrahim EI-Nefiawy, MD, PhD, Department of Human Anatomy \& Embryology, Faculty of Medicine, Ain shams University, Cairo, Egypt., Tel. 01156290585, E-mail: nagwaebrahim@hotmail.com

ISSN: 1110-0559, 2017, Vol 40. , No. 2

\section{INTRODUCTION}

The prime function of the umbilical cord is to insure good quality of fetal intrauterine life as a healthy fetal environment ensures a good birth outcome. Nowadays, it has been recognized that the fetal environment gives clues regarding future health. Its relationship with cardiovascular diseases and diabetes in adulthood is now accepted ${ }^{[1]}$.

Implantation occurs at around 8-10 weeks of gestation and the placenta is formed by the interaction of deciduas basalis of the endometrium and chorionic villi of the fetus. The intervillous blood flow of the utero-placental circulation is recognizable only after the $12^{\text {th }}$ week of gestation $^{[2]}$.
The primitive umbilical ring is formed by the fifth week of development. Later, the umbilical cord functions throughout pregnancy to protect umbilical vessels that travel between the fetus and placenta. The umbilical vein carries oxygenated nutrient-rich blood from the placenta to the fetus, and the umbilical arteries carry deoxygenated, nutrient-depleted blood from the fetus to the placenta ${ }^{[2,3]}$. The circulatory system of the fetus usually includes the entire fetoplacental circulation which encompasses the umbilical vessels that carry fetal blood ${ }^{[4]}$.

Though, many publications to date described the structure of human umbilical vessels at term ${ }^{[5-9]}$, few of them compared the structure of these vessels during gestation ${ }^{[10,11]}$. 


\section{AIM OF THE WORK}

Therefore, we designed this research to study microstructure of human umbilical cord vessels at early gestational periods $(13,16$, and 20 weeks of gestation) to elucidate their developmental characteristics for better understanding of the mechanisms regulating the fetoplacental circulation to improve pregnancy outcome. Light microscopy, immunohistochemistry, and histomorphometry were used.

\section{MATERIAL AND METHODS}

\section{Specimen collection and processing for light microscopy:}

Twelve specimens of human umbilical cords were obtained from fetuses born due to termination of legal, uncomplicated pregnancies at gestational weeks 13,16 , and 20. Segments of human umbilical cords $(2-3 \mathrm{~cm})$ were cut about $10 \mathrm{~cm}$ from the placenta. Specimens were fixed in $10 \%$ neutral formalin in water for 24 hours. Then specimens were dehydrated, processed for preparation of paraffin blocks and sectioned at 5- $\mu \mathrm{m}$ thick. Sections were stained with haematoxylin and eosin (H\&E), Masson Trichrome stain for collagen fibers (nuclei appear dark brown/black or dark red/purple, cytoplasm pink, connective tissue green/blue), Orcein stain for elastic fibers (brown color), and Periodic Acid Schiff (PAS) stain (deep red color) for; carbohydrates (glycogen), reticular fibers (i.e. collagen) in connective tissue, and basement membrane ${ }^{[12]}$. Slides were examined by the light microscope and images were photographed by digital camera attached to the microscope. Some paraffin sections were used for immunohistochemistry. Characterization of tissues was done as described before ${ }^{[13,14]}$.

The study was conducted in accordance with the quality assurance methods. The experimental design and procedures were approved by the ethics Committee of the Faculty of Medicine, Ain Shams University, Egypt.

\section{Immunohistochemistry:}

\section{Primary antibodies:}

(1) Alpha smooth muscle actin: Anti-alpha smooth muscle actin antibody [EPR5368] was used at a dilution of 11000 / on paraffin sections (Abcam pharmaceuticals).

(2) Laminin: Anti-laminin antibody [ab11575] was used at a dilution of 1300/ on paraffin sections (Abcam pharmaceuticals).

\section{Staining technique:}

Immunohistochemical analysis was performed using streptavidin-biotin-peroxidase complex method (SAB). Paraffin sections were deparaffinized in xylene and subjected to heat mediated antigen retrieval in sodium citrate buffer (10mM Sodium Citrate, $0.05 \%$ Tween 20, pH 6.0). Endogenous peroxidase activity was blocked with $0.3 \% \mathrm{H}_{2} \mathrm{O}_{2}$ in methanol for 20 minutes. To minimize non-specific reaction, sections initially were incubated with fetal calf serum for $30 \mathrm{~min}$. at $37^{\circ} \mathrm{C}$. Thereafter, sections were incubated with the primary antibody overnight at $4^{\circ} \mathrm{C}$ and rinsed in Phosphate Buffer Saline (PBS). Then the secondary antibody (Horse radish peroxidase (HRP) labelled biotin antibody) was applied to the slides at $37^{\circ} \mathrm{C}$ for $30 \mathrm{~min}$. Finally, sections were treated with diaminobenzidine $-\mathrm{H}_{2} \mathrm{O}_{2}$ mixture and counterstained with haematoxylin. Negative control staining was performed after omitting the primary antibody.

\section{Image analysis \& morphometry:}

Measurements were performed on H\&E-stained sections using Image Analysis software. Six readings were obtained from non-overlapping fields for each of examined sections of the three groups. Parameters "one and two" were made at a magnification of $\times 100$ while parameter three done at magnification of $\times 40$. The mean values were estimated.

\section{The following parameters were quantitated:}

(1) Whole vascular wall thickness (in $\mu \mathrm{m}$ ). It was measured as the distance between one point on the lining endothelium and the farthest point on the outer segment of the vessel wall.

(2) Diameter of the vascular lumen (internal diameter) (in $\mu \mathrm{m}$ ). The widest part of the lumen was chosen. The longest line connecting two points located on the vascular endothelium was used as the vascular lumen diameter.

(3) Diameter of the umbilical cord (in $\mu \mathrm{m}$ ) As the cords almost had more or less oblong configuration, we used the distance between farthest two points on the outline of the umbilical cord as an indicator of Wharton's jelly content

\section{Statistical analysis:}

Statistical analysis was done using one-way analysis of variance (ANOVA) test. The data were presented in the form of mean \pm standard deviation (SD). The difference was insignificant at $P>0.05$, significant at $P<0.05$ and highly significant at $P<0.01$. 


\section{RESULTS}

\section{Histology and immunohistochemistry:}

Examination of stained sections of the umbilical cords (UC) of 13 gestational weeks revealed the presence of three vessels embedded in the embryonic connective tissue (Wharton's jelly). The two umbilical arteries (UA) demonstrated apparently thick walls and constricted lumens whereas, the single umbilical vein (UV) showed thinner wall and patent lumen (Fig. 1). Umbilical cord was covered by amniotic epithelium that was formed of a single layer of flat cells (Fig. 2).The walls of the three vessels were composed of two layers; an inner intima and an outer media.

The intimae of the umbilical vessels were formed of single layer of endothelial cells. Wide areas of endothelial loss were observed. Inflammatory cells were observed attached to the denuded endothelial surface (Fig. 3). Cells with the morphology of smooth muscle cells were seen travelling through endothelial cells of the intima (Fig. 4). The basement membrane of the endothelial cells was interrupted and not observed beneath areas of endothelial damage using PAS stain (Fig. 5). Orcein stain demonstrated thin, interrupted, ill-developed internal elastic lamina (IEL) in both umbilical artery (UA) and umbilical vein (UV) as shown in (Fig. 6). There was no external elastic lamina.

The media of umbilical vessels consisted mainly of one layer of concentric circular smooth muscle cells (SMC) with elongated rod shaped nuclei. The smooth muscle fibers were widely separated with plentiful extracellular matrix and revealed pale stained cytoplasm in H\&E stained sections (Figs. 3 and 4). External laminae of SMCs were absent in PAS stained sections (Fig. 5). Immunohistochemistry by $\alpha$-smooth muscle actin revealed faint, weak immune staining at the SMCs of the media in contrast to dark staining at the endothelial cell layer (Fig. 7). Laminin immunohistochemistry revealed homogenous positive reaction involving the whole vessel (Fig. 8). Collagen fibers were nearly absent between SMCs of the media or in the sub-endothelial layer using Masson's Trichrome stain (Fig. 9).

Wharton's jelly cellular elements were more condense in close proximity to umbilical vessels whereas, and became scarce away from them. There was a lack of fibers or blood vessels in the mesenchymal tissue of Wharton's jelly (Fig. 1).

Examination of 16 gestational weeks UC sections revealed the presence of three vessels; two arteries and one vein embedded in Wharton's jelly.

Endothelium lining of umbilical vessels revealed areas of endothelial loss with attachment of inflammatory cells to the raw surface (Fig. 10). Localized areas of intimal thickening due to longitudinally oriented SMCs that apparently migrated from the media were seen (Fig. 11). Massive regions of endothelial cell damage with; fragmented cells, nuclear chromatin margination, hyaline material deposition, and cell debris were seen. Extruded or sloughed necrotic tissue in the lumen of the artery was also observed (Fig. 12). Proliferating and dividing SMCs that were observed (Fig. 13). Orcein stain demonstrated more thick and developed internal elastic lamina than that of 13 weeks of gestation. It was interrupted at sites of intimal injury (Fig. 14). There was no elastic layer at the intima-media interface (external elastic lamina, EEL).

The media of umbilical vessels of this gestational age was formed of SMCS arranged as circular muscle layer. The cytoplasm of SMCs revealed more deep acidophilic staining on H\&E stained sections compared with 13 gestational weeks. There was abundant ground substance between SMCs (Figs. 10, 11, 13). Immunohistochemistry with $\alpha$-smooth muscle actin demonstrated moderate degree of immune reactivity at the inner layers of SMCs of media in contrast to strong reaction at the outer muscle layers. The endothelium in addition revealed strong immune reaction (Fig. 15 a and b). Masson's trichrome staining revealed nearly absent collagen fibers from umbilical vessel walls (Fig. 16).

Spindle shaped cells of Wharton's jelly in close proximity to vascular walls revealed strong positive immune reaction to $\alpha$-smooth muscle actin immunohistochemistry (Fig. 15).

Examination of 20 gestational weeks UC sections showed three well developed vessels embedded in Wharton's jelly. The UV demonstrated relatively thinner wall and patent lumen compared with the two UAs (Fig. 17). Amniotic membrane was formed of cuboidal epithelium (Fig. 18).

Endothelium lining umbilical vessels at this age appeared mostly intact compared with the previous two groups (Fig. 19). The neointimal thickening formed of migrating, longitudinally oriented SMCs formed a complete well-developed layer beneath the endothelium (Fig. 20). Mature, secretory SMCs were observed beneath the neointima in the outer circular muscle layer of the media where rich components of the extracellular matrix were detected (Fig. 21). PAS staining demonstrated; well-developed intact basal lamina of the endothelium, external lamina of the SMCs, and PAS-positive material in the cytoplasm of the SMCs indicating their rich carbohydrate content and secretory activity (Fig. 22). Orcein staining revealed thick, well-developed, double layered internal elastic lamina compared with previous two groups (Fig. 23).

Cytoplasm of SMCs was deeply acidophilic in $\mathrm{H} \& \mathrm{E}$ sections compared with previous two age 
groups (Fig. 21). Immunohistochemistry using $\alpha$-smooth muscle actin illustrated dark positive staining that was more observable in the outer circular muscle layer of the media and at the intimal endothelium (Fig. 24). Laminin immunohistochemistry revealed negative immune staining of the SMCs forming the neointima while the outer circular muscle layer of the media showed deep positive staining (Fig. 25). Masson trichrome stain demonstrated dense collagen fibers between smooth muscle cells and beneath the endothelium in both UA and UV (Fig. 26).

Spindle shaped cells of Wharton's jelly next to umbilical vessel walls revealed dark positive immune staining for $\alpha$-smooth muscle actin (Fig. 24).

\section{Histomorphometric results:}

\section{(1) Whole vascular wall thickness (in $\mu \mathrm{m}$ ):}

Mean 13 week UA wall thickness was $(82.72 \pm 6.62)$, while that of 16 week UA was $(95.75 \pm 12.37)$. Mean 20 week UA wall thickness was $(262.89 \pm 20.34)$. There was a highly statistically significant increase in arterial wall thickness at 20 weeks compared with 13 and 16 weeks $(P<0.0001)$.

Mean 13 week UV wall thickness was $(36.82 \pm 3.11)$, while that of 16 week UV was $(68.96 \pm 7.64)$. Mean 20 week UV total wall thickness was $(165.62 \pm 20.62)$. There was a highly statistically significant increase in venous wall thickness at 20 weeks compared with previous two stages $(P<0.0001)$. Results are presented in histogram I.

(2) Diameter of vascular lumen (internal vascular diameter) (in $\mu \mathrm{m})$ :

Mean 13 week UA lumen diameter was (50.94 \pm 1.27$)$, while that of 16 week UA was $(65.99 \pm 1.02)$. Mean 20 week UA lumen diameter was $(85.51 \pm 1.04)$. There was a statistically significant increase in arterial lumen diameter across sequential gestational days compared with 13 weeks $(P<0.005)$.

Mean 13 week UV lumen diameter was $(90.40 \pm 1.52)$, while that of 16 week UV was $(107.74 \pm 1.51)$. Mean 20 week UV lumen diameter was $(126.27 \pm 1.50)$. There was a statistically significant increase in venous lumen diameter across sequential gestational days compared with 13 weeks $(P<0.005)$. Results are presented in histogram II.

(3) Diameter of the umbilical cord (as indicator of Wharton's jelly content):

Mean 13-week umbilical cord diameter was $(749.797 \pm 1.12)$, while that of 16 -week was $(841.992 \pm 1.64)$. The mean 20 -week umbilical cord diameter was $(4260.10 \pm 1.82)$. There was no significant difference in cord diameter between 13 and 16 gestational weeks. However, there was highly significant increase in cord diameter at 20 weeks of gestation compared with previous two stages $(P<0.0001)$. Results are presented in histogram III.

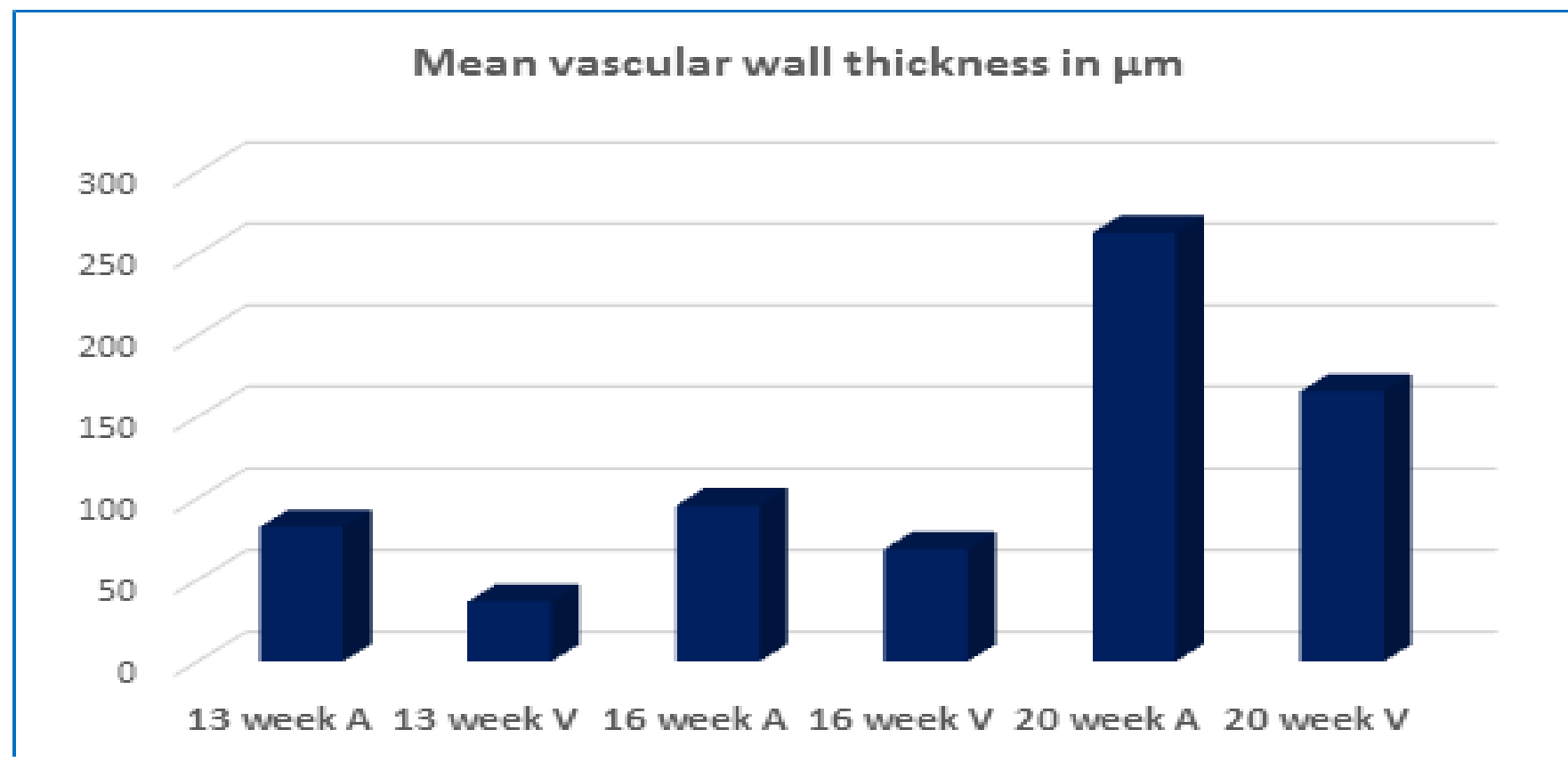

Histogram I: Vascular wall thickness in $\mu \mathrm{m}$.

Highly statistical significant increase in umbilical arteries \& veins wall thickness is obtained only at the $20^{\text {th }}$ week of gestation compared to the $13^{\text {th }}$ and $16^{\text {th }}$ weeks. 


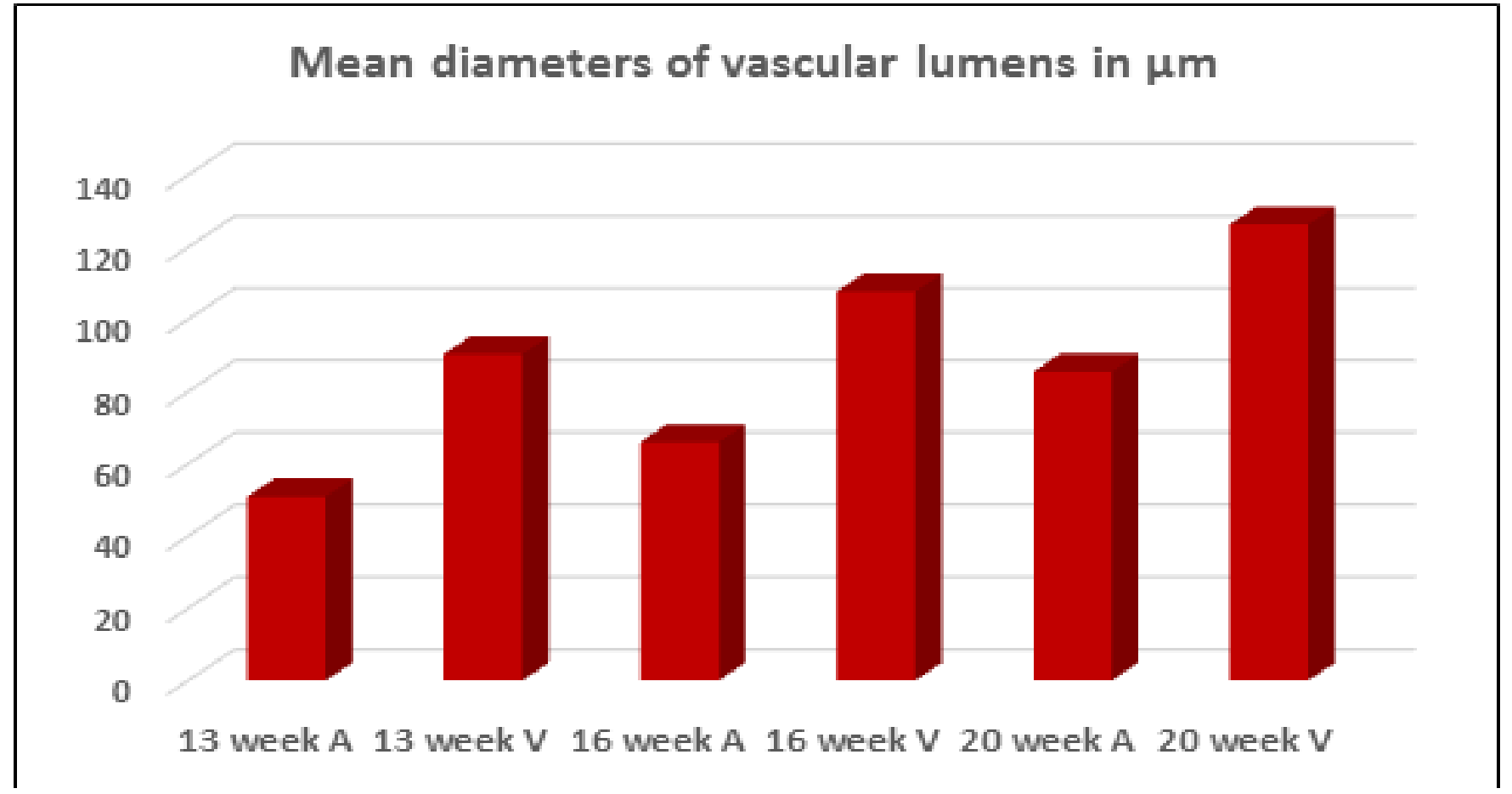

Histogram II: Diameter of vascular lumen (internal vascular diameter) in $\mu \mathrm{m}$.

There was statistically significant increase in umbilical artery \& vein lumen diameter across sequential gestational days.

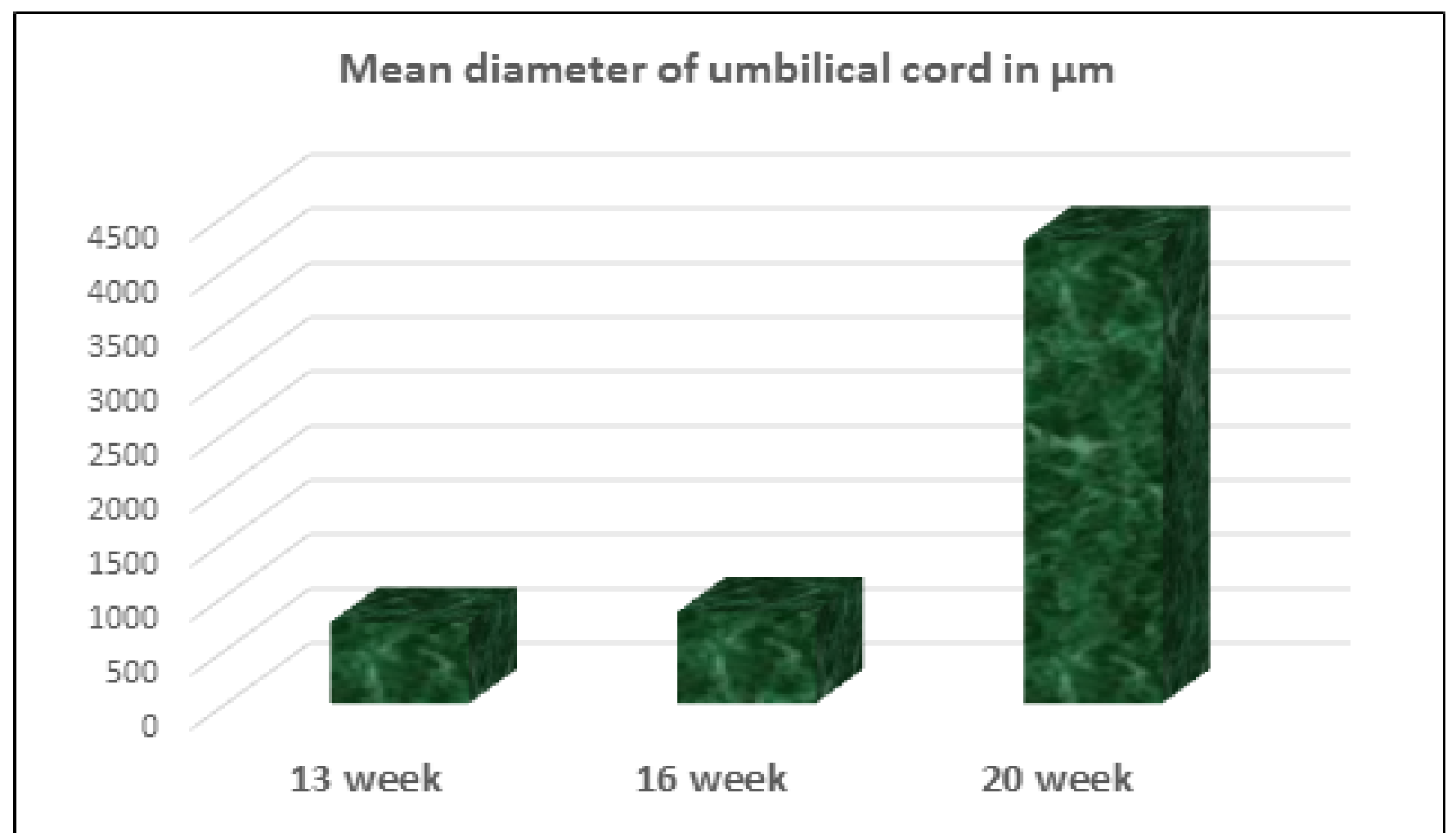

Histogram III: Diameter of the umbilical cord (as indicator of Wharton's jelly content).

There was no significant difference in cord diameter between the $13^{\text {th }}$ and $16^{\text {th }}$ gestational weeks. However, there was highly significant increase in cord diameter at the $20^{\text {th }}$ week of gestation compared with previous two stages. 


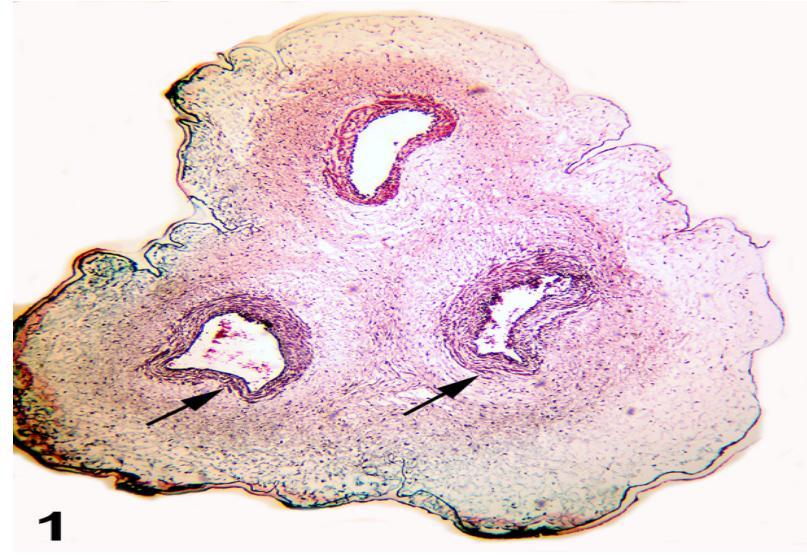

Fig. 1: Photomicrograph of a section of umbilical cord (13 weeks of gestation) showing two umbilical arteries $(\uparrow)$ and one vein. The adventitia of blood vessels is formed by embryonic mucoid connective tissue of Wharton's jelly. The wall of the cord is surrounded by amniotic epithelium. Note hypercellularity (deep acidophilia) of mucoid connective tissue close to the vessels. The area of Wharton's jelly at the periphery is pale.

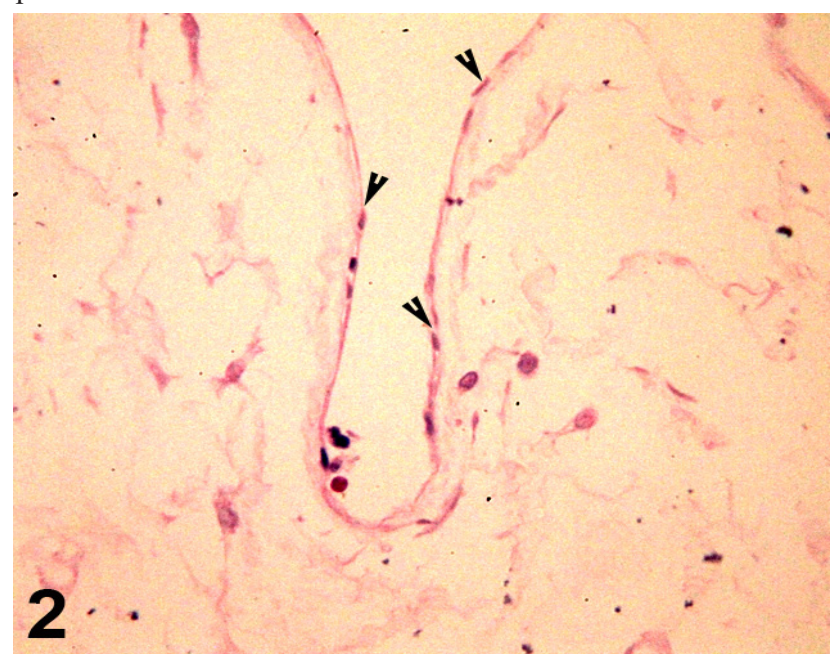

Fig. 2: Photomicrograph of a section of umbilical cord (at the $13^{\text {th }}$ week of gestation) showing amniotic epithelium ( $\boldsymbol{\Lambda})$ formed of a single layer of flat cells that cover pale stained embryonic mucoid connective tissue (Wharton's jelly).

$\mathrm{H} \& \mathrm{E} ; \times 400$

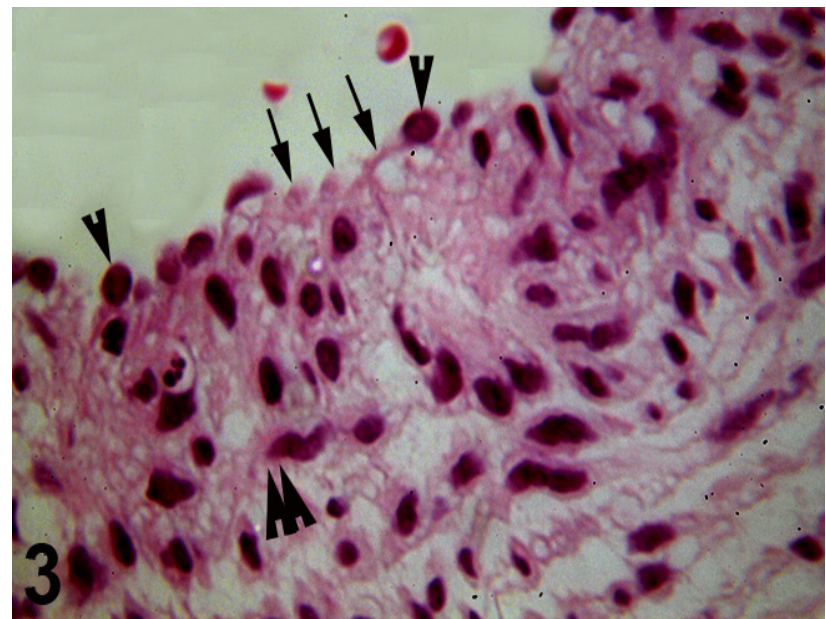

Fig. 3: Photomicrograph of a section of umbilical vessel (at the $13^{\text {th }}$ week of gestation) showing loss of the endothelial cells of the intima ( $\uparrow \uparrow)$ with attachment of inflammatory cells $(\boldsymbol{\Delta})$ to the denuded areas. Notice pale stained smooth muscle cells $(\boldsymbol{\Lambda} \boldsymbol{\Delta})$ of the media.

$\mathrm{H} \& \mathrm{E} ; \times 1000$

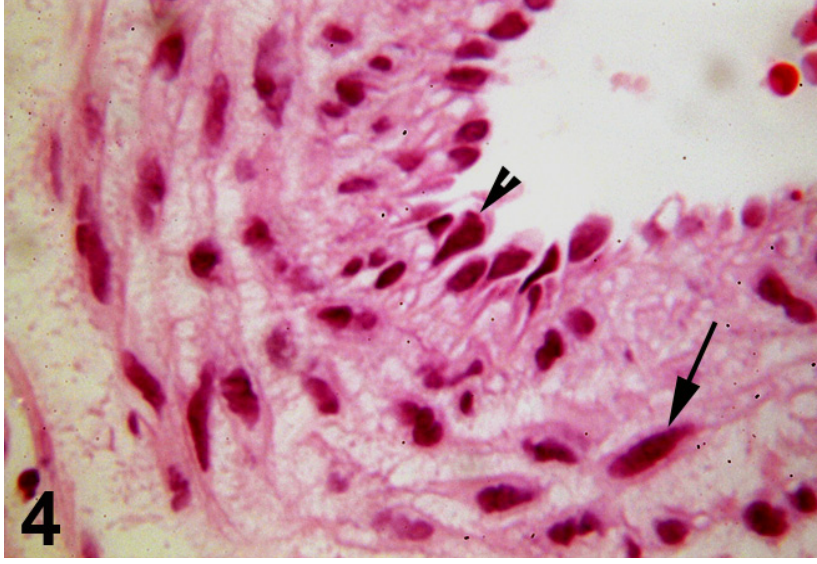

Fig. 4: Photomicrograph of a section of umbilical vessel (at the $13^{\text {th }}$ weekof gestation) showing smooth muscle-like cells $(\boldsymbol{\Lambda})$ apparently migrating from the lumen of the blood vessel through the intima. Note smooth muscle cell with elongated rod-shaped nucleus $(\uparrow)$. $\mathrm{H} \& \mathrm{E} ; \times 1000$

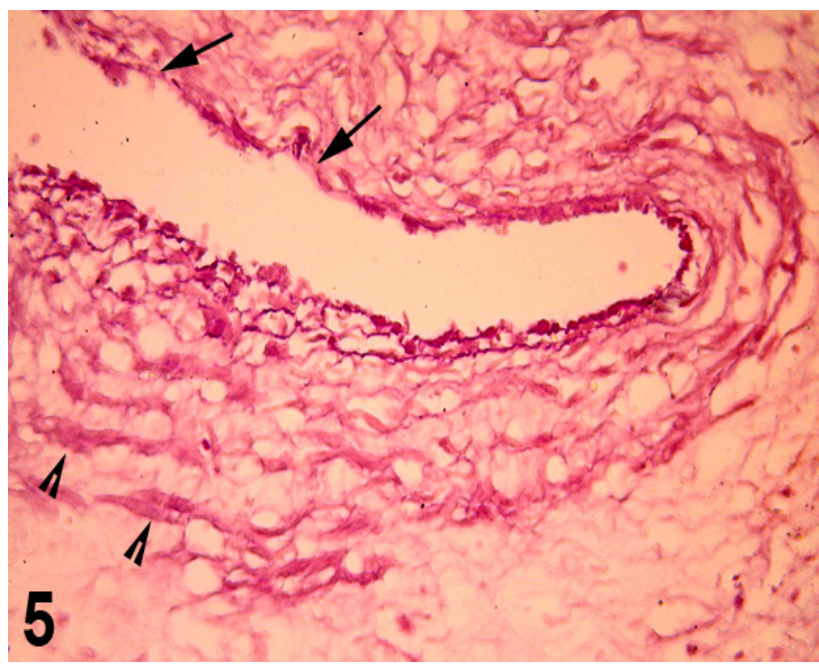

Fig. 5: Photomicrograph of a section of umbilical vessel (13 weeks of gestation) showing absent basal lamina ( $\uparrow$ ) beneath the disrupted endothelium. Notice absence of external lamina $(\boldsymbol{\Lambda})$ for the undifferentiated smooth muscle fibers. $\quad$ PAS $\times 400$.

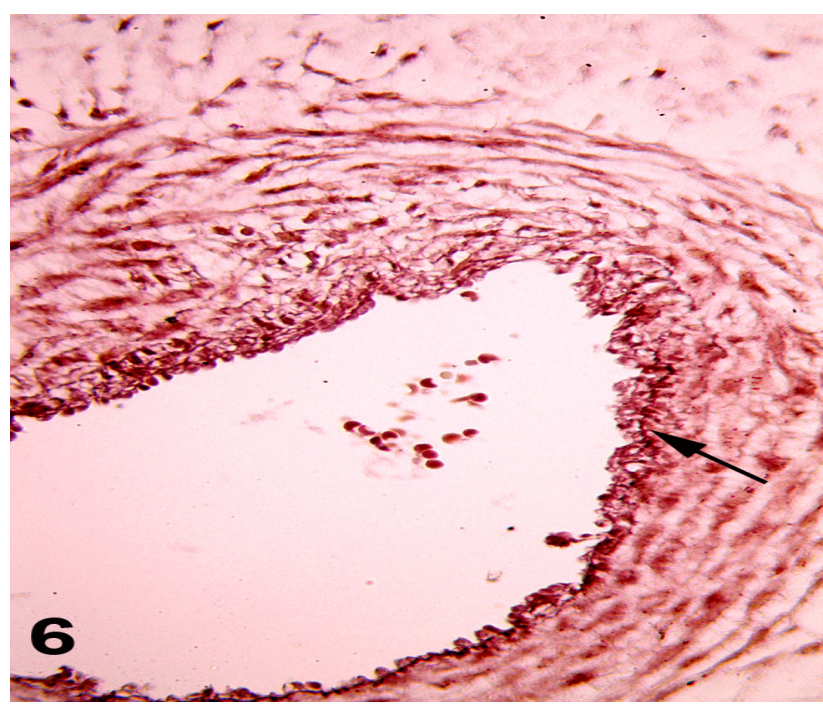

Fig. 6: Photomicrograph of a section of umbilical vein (at the 13th weekof gestation) showing interrupted, thin internal elastic lamina $(\uparrow)$.

Orcein; $\times 400$ 


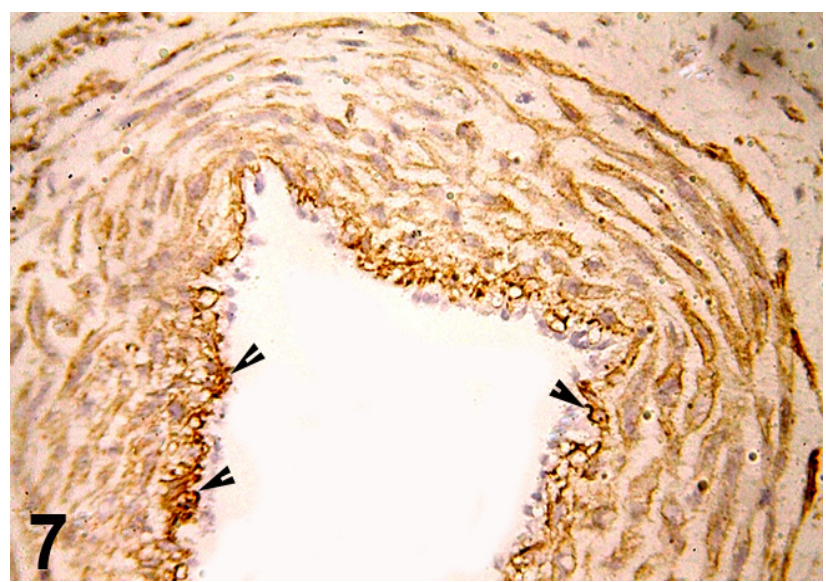

Fig. 7: Photomicrograph of a section of umbilical vessel (13 weeks of gestation) showing weak reaction at the smooth muscle cells in contrast to dark stained endothelial cells $(\boldsymbol{\Delta})$. Immunohistochemistry by $\alpha$-smooth muscle actin antibody $\times 400$

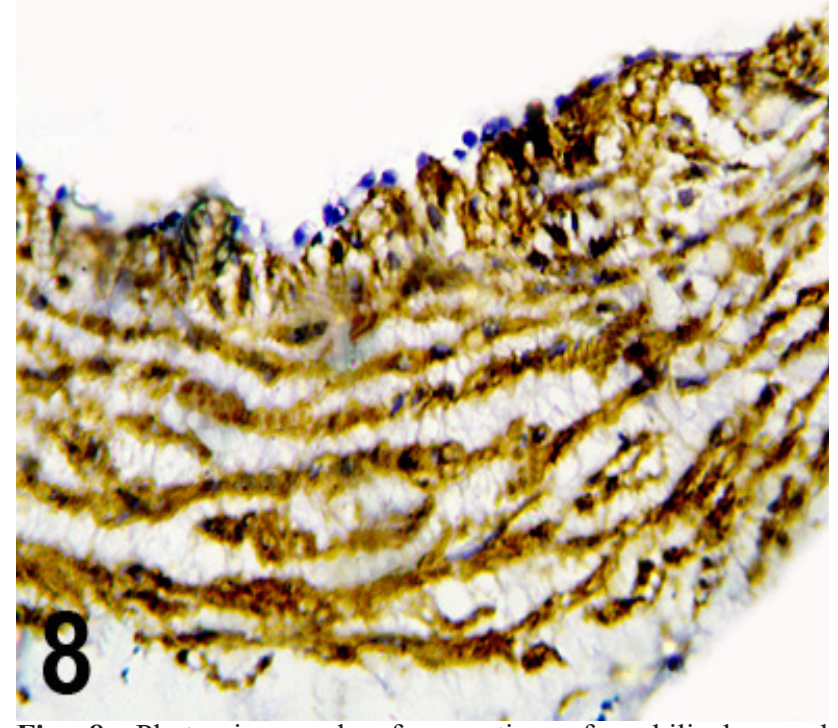

Fig. 8: Photomicrograph of a section of umbilical vessel (at the $13^{\text {th }}$ week of gestation) showing positive immune reaction of basal laminae of cells throughout the vessel layers. Immunohistochemistry by laminin antibody $\times 400$.

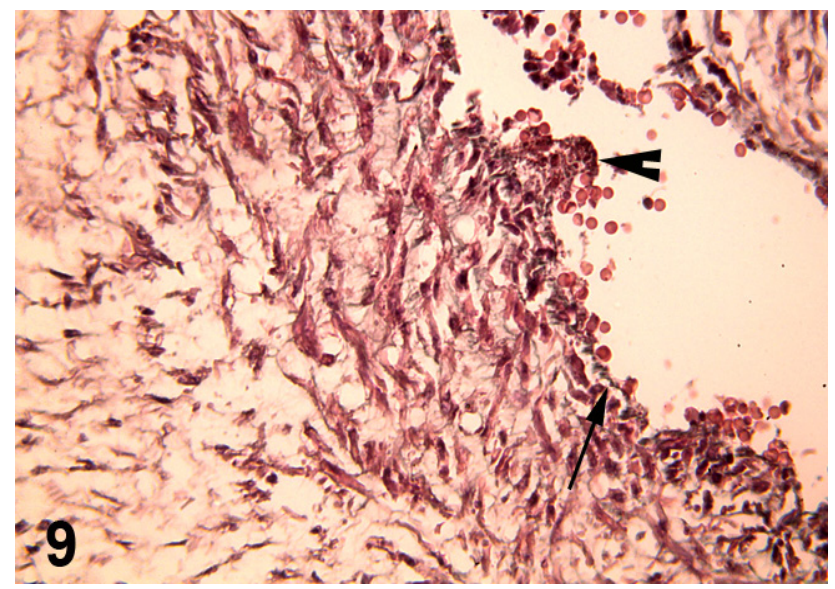

Fig. 9: Photomicrograph of a section of umbilical artery (at the $13^{\text {th }}$ week of gestation) showing absence of collagen fibers in between muscle fibers and in sub-endothelial layer. Notice cell debris with attached inflammatory cells at the intima ( $\boldsymbol{\Delta})$ and note also basal lamina ( $\uparrow)$ of the endothelium.

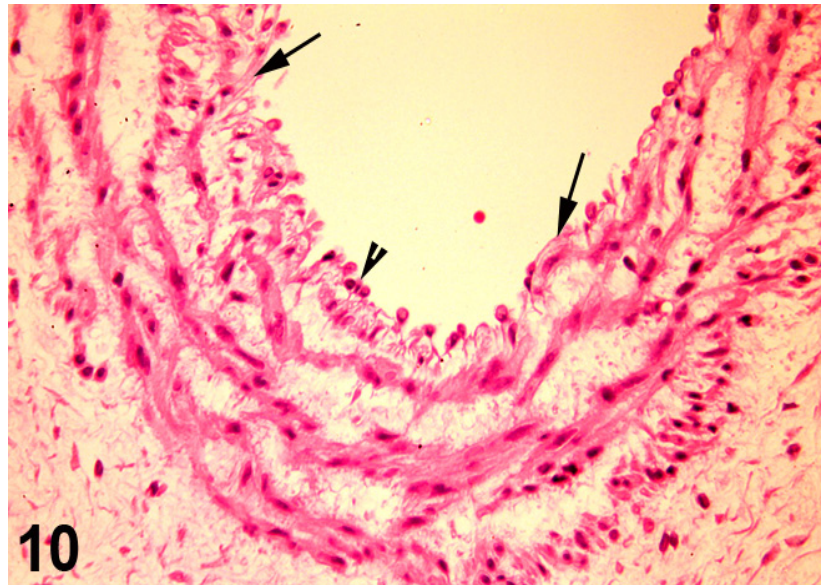

Fig 10: Photomicrograph of a section of umbilical vein (at the $16^{\text {th }}$ week of gestation) showing areas with loss of endothelial cells $(\uparrow)$ with attachment of inflammatory cells $(\boldsymbol{\Delta})$ to the disrupted raw endothelial surface. Notice that smooth muscle cells of the media appear more developed (more acidophilic cytoplasm) than 13 weeks of gestation and are widely separated. H\&E; $\times 400$.

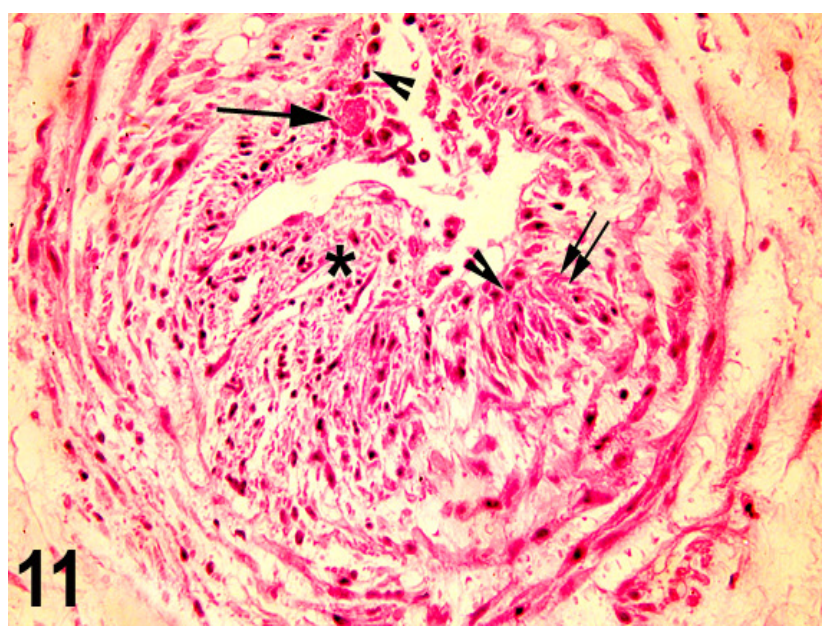

Fig. 11: Photomicrograph of section of umbilical artery (at the $16^{\text {th }}$ week of gestation) showing an area of intimal thickening $(\uparrow \uparrow)$ due to proliferated, migrated, longitudinally oriented smooth muscle cells beneath the intima. Notice extensive cell damage, fragmented bodies and cell debris (star) in the intima and in vessel lumen, hyaline material deposition $(\uparrow)$, adhered inflammatory cells $(\boldsymbol{\Delta})$.

$\mathrm{H} \& \mathrm{E} ; \times 400$.

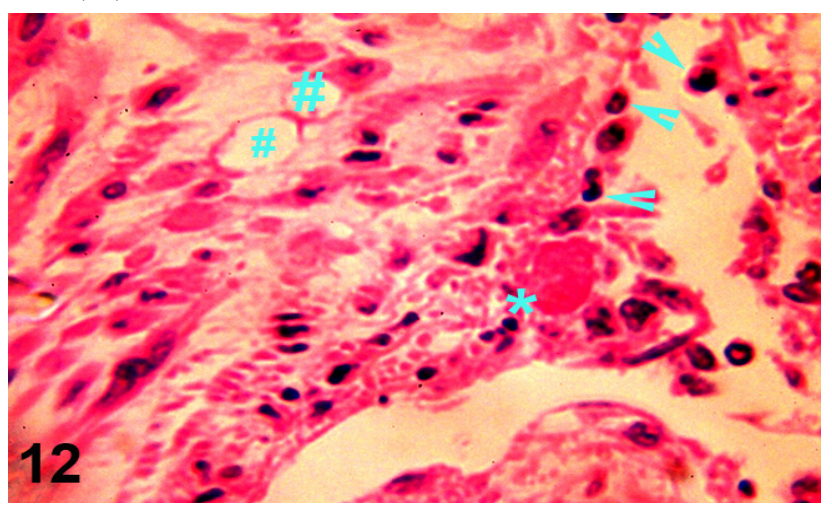

Fig. 12: Photomicrograph of section of umbilical artery (at the $16^{\text {th }}$ week of gestation) showing high magnification of previous section in fig. 11. Notice destruction of endothelial cells resulting in cellular debris (star) inside the lumen of the vessel. Numerous inflammatory cells $(\boldsymbol{\Delta})$ are attached to the lumen of the vessel. Note medial smooth muscle fibers showing degenerative changes (\#). $\mathrm{H} \& \mathrm{E} ; \times 1000$ 


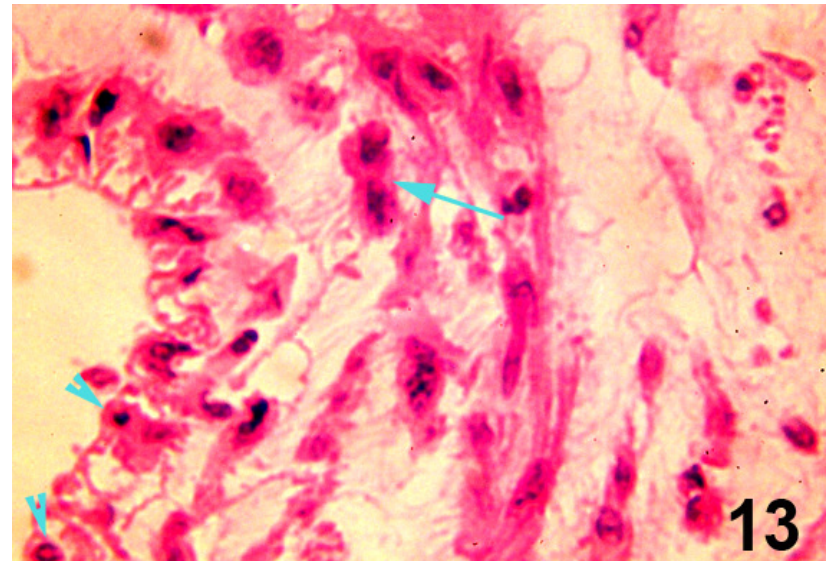

Fig. 13: Photomicrograph of a section of umbilical vessel (at the $16^{\text {th }}$ week of gestation) showing proliferating dividing smooth muscle cells $(\uparrow)$. Note attached inflammatory cells $(\boldsymbol{\Lambda})$ to denuded endothelial surface. $\mathrm{H} \& \mathrm{E} ; \times 1000$.

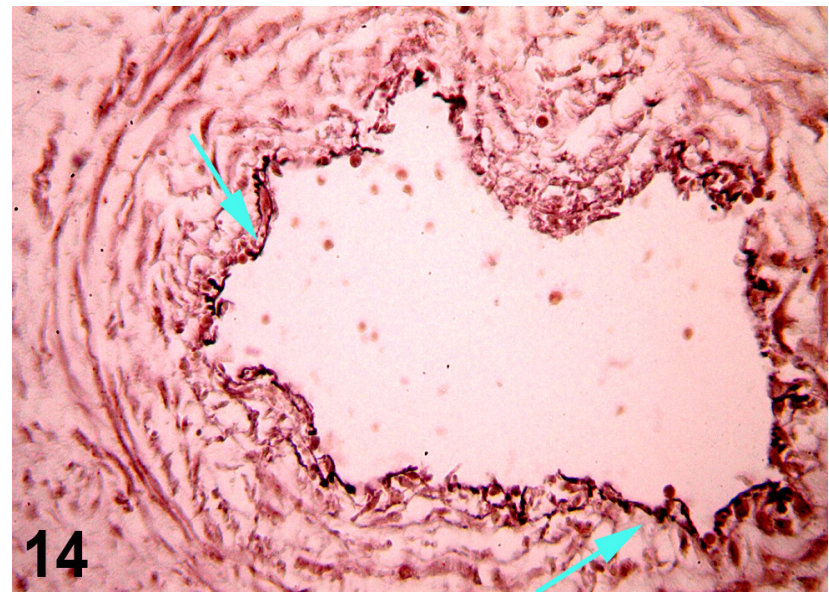

Fig. 14: Photomicrograph of a section of umbilical artery (at the $16^{\text {th }}$ week of gestation) showing more developed (thick) internal elastic lamina $(\uparrow)$ than that of 13 weeks but interrupted at sites of endothelial damage.

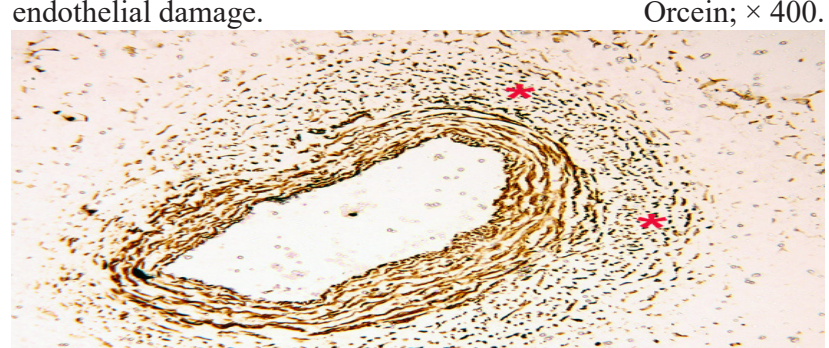

$15 a$

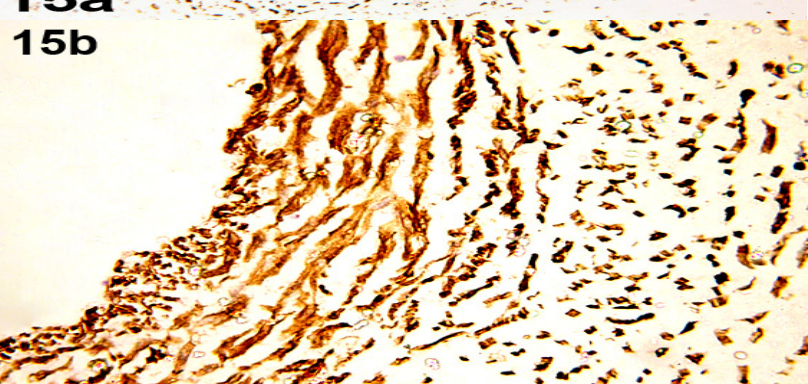

Fig. 15 a \& b: Photomicrographs of sections of umbilical vessel (at the $16^{\text {th }}$ week of gestation) showing strong immune reaction at the endothelium \& outer layer of smooth muscle cells. Inner medial muscular layer illustrates weaker reaction. Notice the strong immune reaction in the mesenchymal cells (star) of Wharton's jelly adjacent to the wall of the vessel. Immunohistochemistry by $\alpha$-smooth muscle actin antibody (a) $\times$ $100,(b) \times 400$

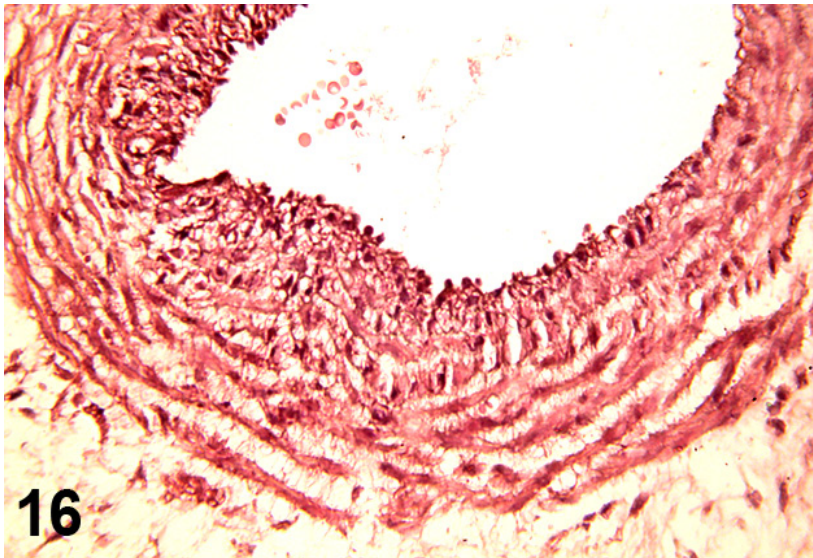

Fig. 16: Photomicrograph of a section of umbilical vessel (UA, a the $16^{\text {th }}$ week of gestation) showing nearly absent collagen fibers between muscle fibers. Masson's trichrome $\times 400$.

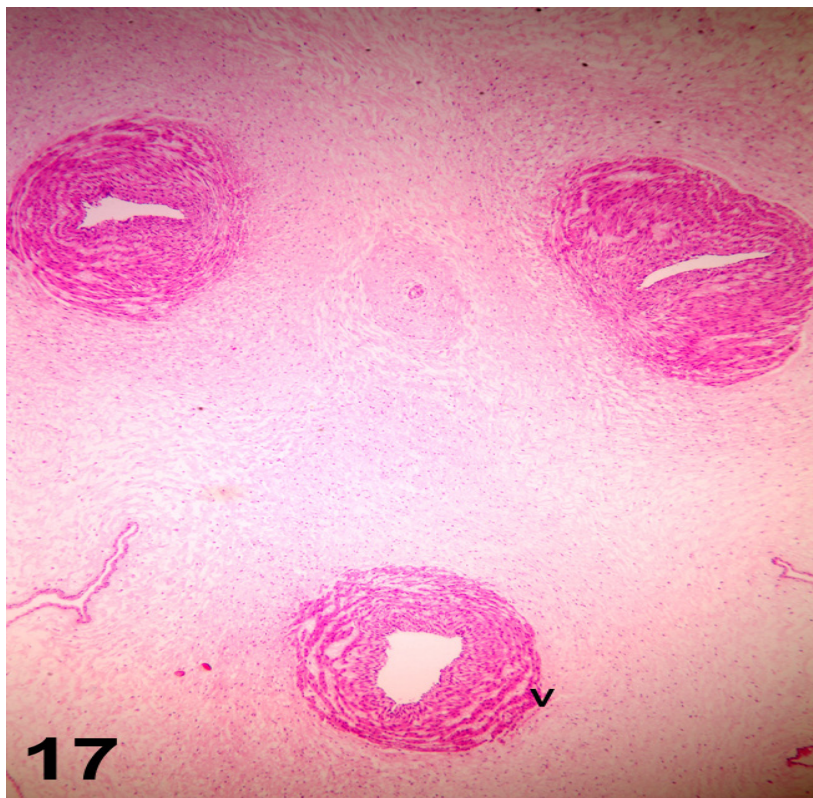

Fig. 17: Photomicrograph of a section of umbilical cord (20 weeks of gestation) showing two umbilical arteries and one vein (V).

$\mathrm{H} \& \mathrm{E} ; \times 40$

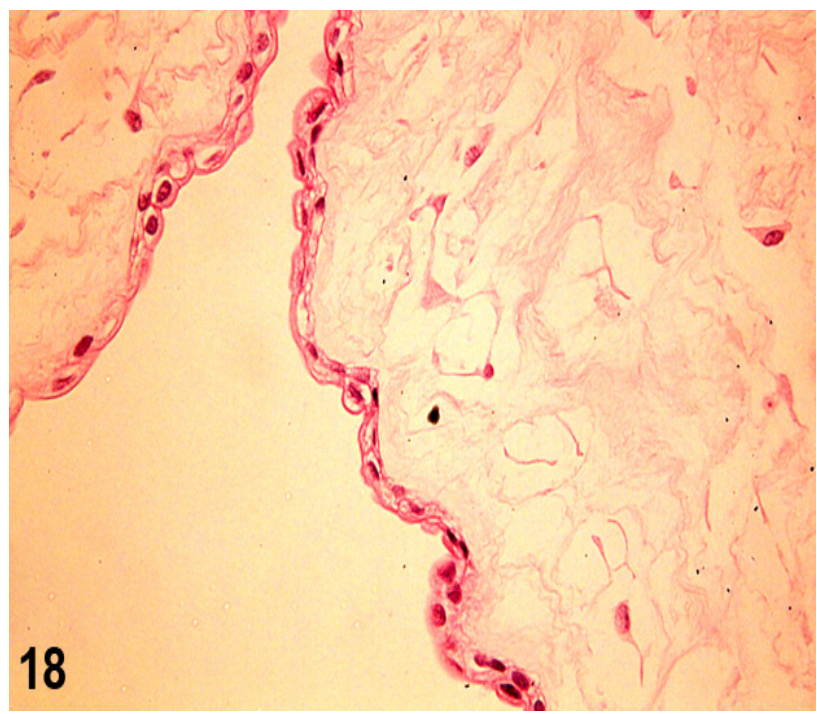

Fig. 18: Photomicrograph of a section of umbilical cord (at the $20^{\text {th }}$ week of gestation) showing amniotic membrane covering the cord formed of cuboidal epithelial cells $\mathrm{H} \& \mathrm{E} ; \times 1000$ 


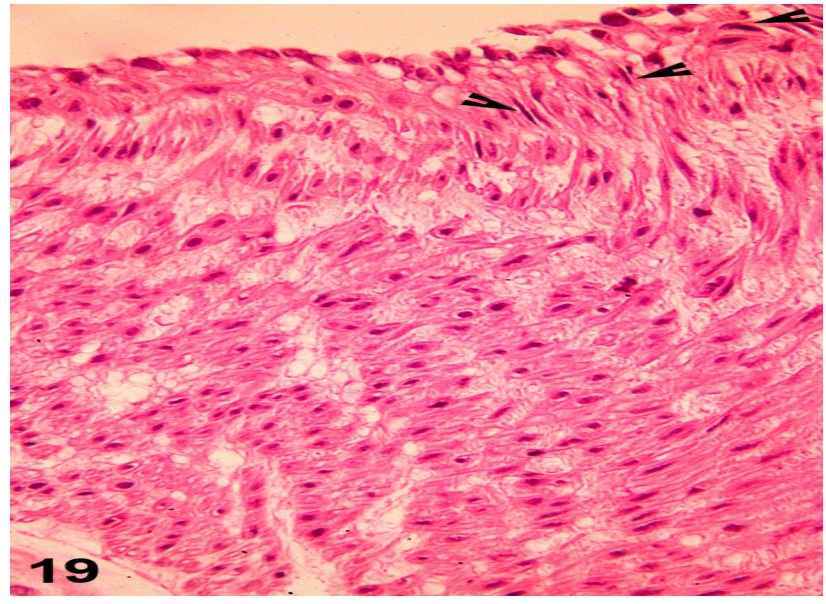

Fig. 19: Photomicrograph of a section of umbilical artery (at the $20^{\text {th }}$ week of gestation) showing media formed of two layers, inner longitudinal \& outer circular. Notice the thick wall of UA and the migrating smooth muscle cells $(\boldsymbol{\Delta})$ towards the intima. $\mathrm{H} \& \mathrm{E} ; \times 400$.

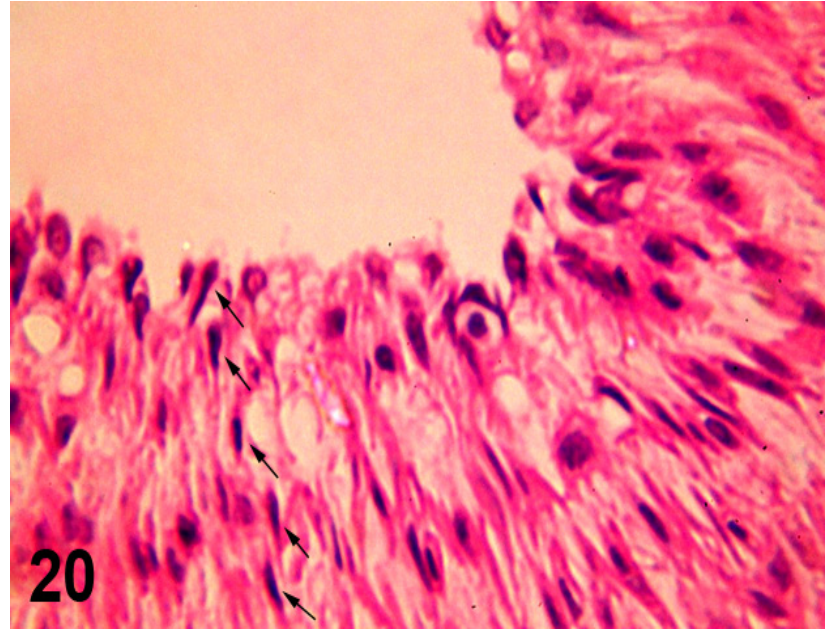

Fig. 20: Photomicrograph of a section of umbilical vessel (at the $20^{\text {th }}$ week of gestation) showing neointimal (intimal hyperplasia, inner longitudinal) smooth muscle cells. Notice smooth muscle cells migrating and projecting through the endothelium of intima $(\uparrow)$. $\mathrm{H} \& \mathrm{E} ; \times 1000$.

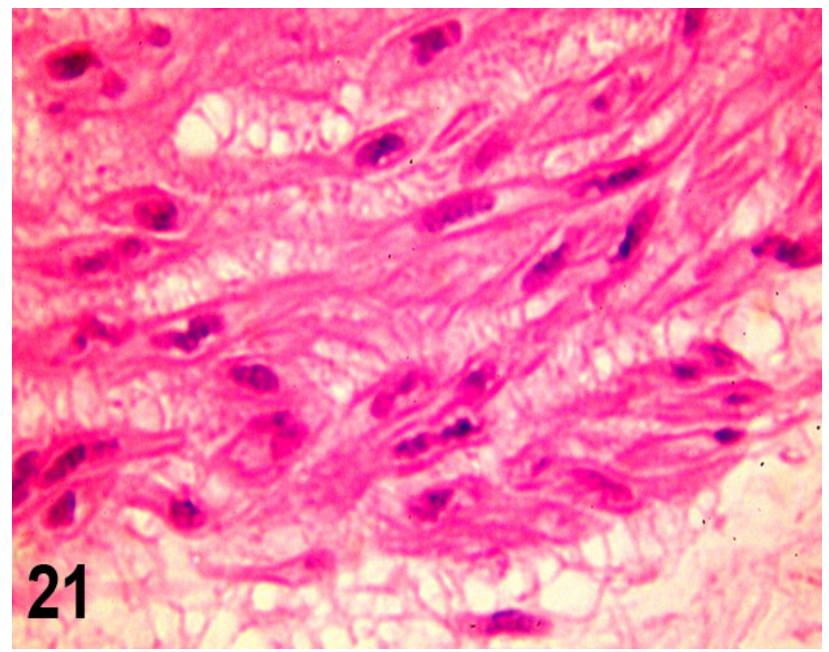

Fig. 21: Photomicrograph of a section of umbilical vessel (at the $20^{\text {th }}$ week of gestation) showing mature smooth muscle cells manifested by deep acidophilic cytoplasm and presence of extracellular matrix components like collagen fibers.

$\mathrm{H} \& \mathrm{E} ; \times 1000$

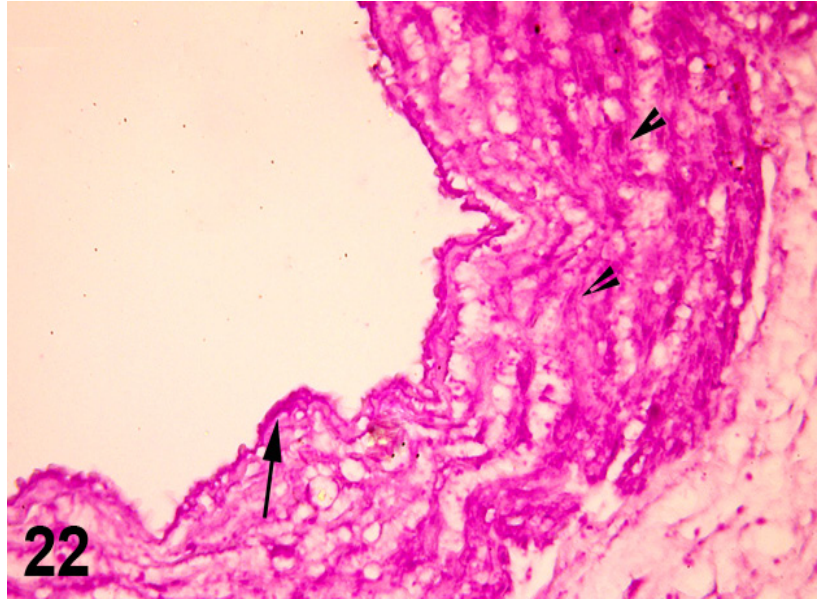

Fig. 22: Photomicrograph of a section of umbilical vessel (at the $20^{\text {th }}$ week of gestation) showing PAS reaction at basal lamina of endothelium ( $\uparrow)$ and external lamina of smooth muscle cells $(\boldsymbol{\Delta})$ and at the cytoplasm of medial musculature. PAS; $\times 400$.

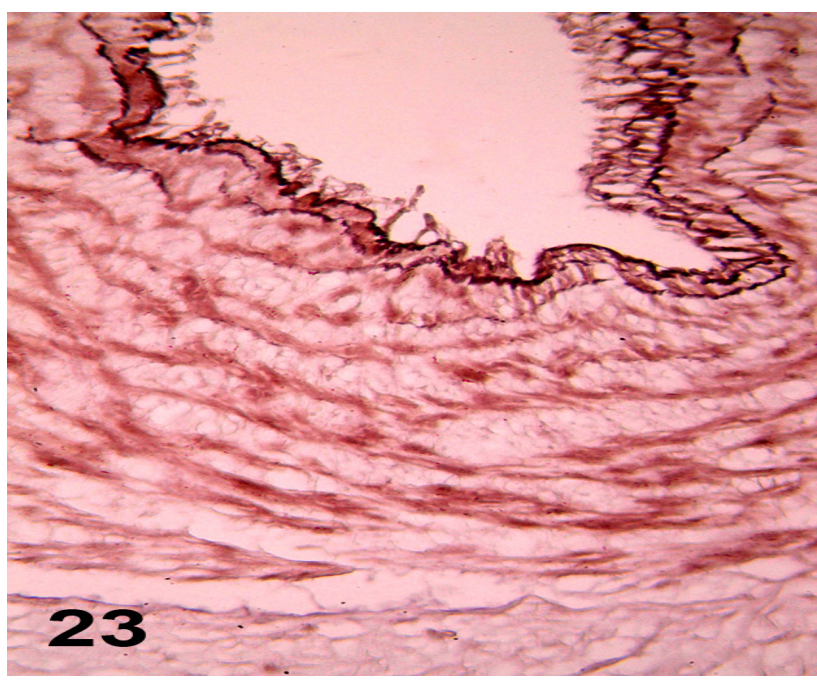

Fig. 23: Photomicrograph of a section of umbilical vessel $(20$ weeks of gestation) showing double layered well developed internal elastic lamina. Orcein; $\times 400$.

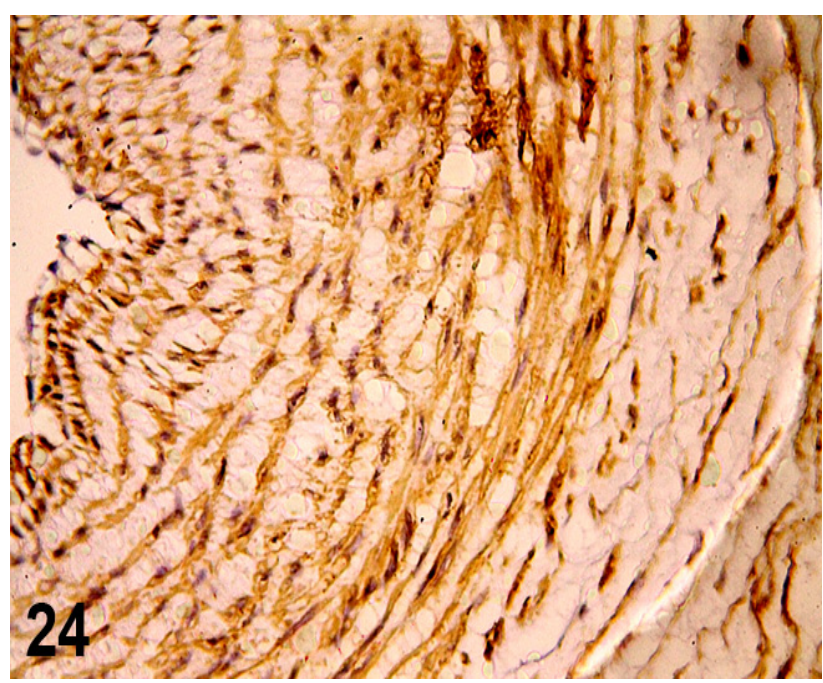

Fig 24: Photomicrograph of a section of umbilical vessel (at the 20th week of gestation) showing strong positive immune reaction at the endothelium \& outer layer of smooth muscle cells. Inner muscular layer illustrates weaker reaction. Immunohistochemistry by $\alpha$-smooth muscle actin antibody $\times 400$. 


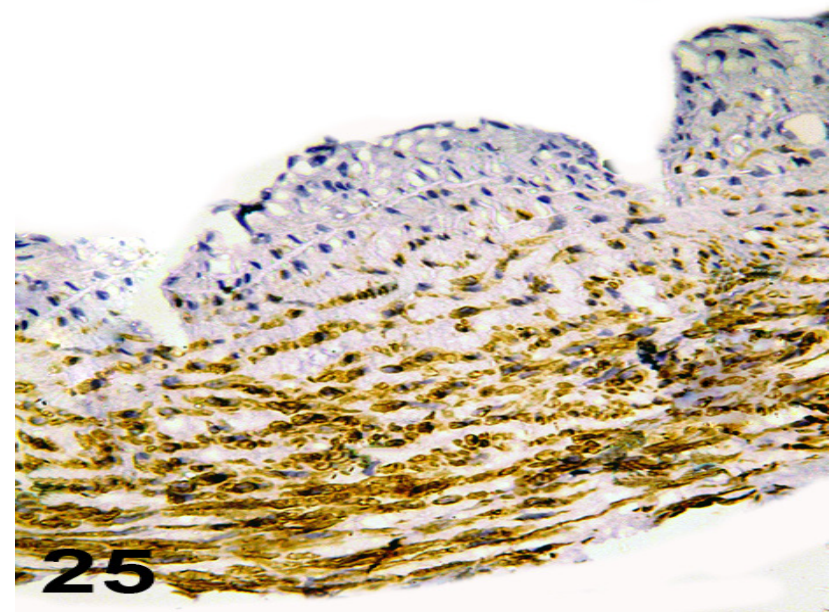

Fig. 25: Photomicrograph of a section of umbilical vessel (at the $20^{\text {th }}$ week of gestation) showing strong positive immune reaction at outer layer of smooth muscle cells. Inner muscular layer forming neointima illustrates negative reaction. Immunohistochemistry by laminin antibody $\times 400$.

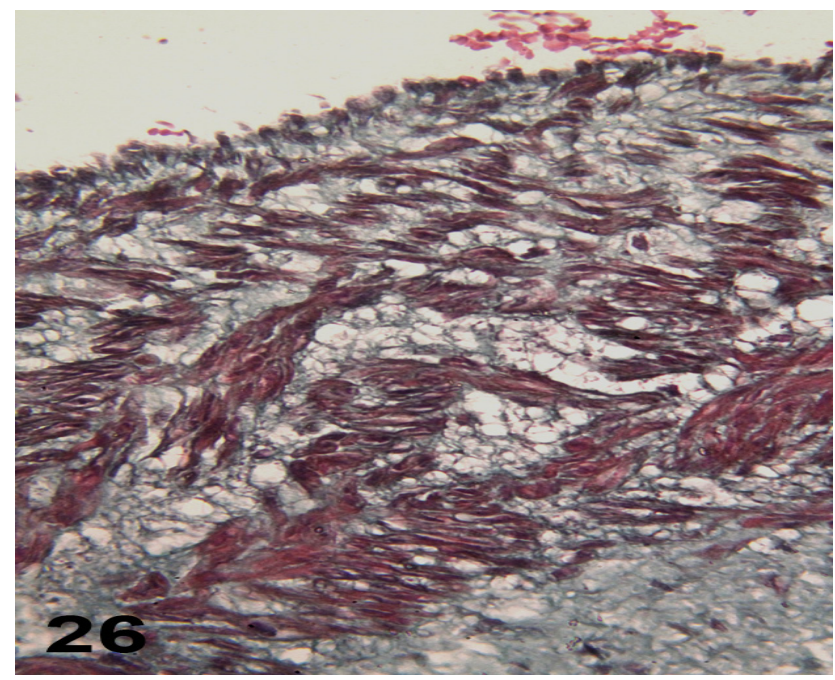

Fig. 26: Photomicrograph of a section of umbilical vessel (at the $20^{\text {th }}$ week of gestation) showing dense collagen fibers in vascular wall beneath the endothelium and between muscle cells of the media.

Masson's trichrome $\times 400$.

\section{DISCUSSION}

In the present study, we investigated the microstructural changes of the umbilical cord vessels at the $13^{\text {th }}$, $16^{\text {th }}$, and $20^{\text {th }}$ weeks of gestation. Light microscopy, immunohistochemistry, and morphometry were utilized.

In view of our findings, development of UVs seems to be the result of a continuous process of vascular remodeling initiated by the stress of hemodynamic forces of the fetoplacental circulation and aided by an environment rich in stem cells provided by the umbilical cord blood and mesenchymal cells of Wharton's jelly.

Our research demonstrated that the wall of the umbilical vessels (UVs) was formed of inner intima and outer media. There was no external elastic lamina, adventitia, or vasa vasorum. Endothelial cells of intima showed vacuolations in $H \& E$ preparations whereas, it demonstrated positive reaction for PAS stain suggesting rich carbohydrate content Sexton et al. ${ }^{[1]}$ reported that endothelial cells of UVs retain excess glycogen throughout gestation particularly umbilical artery. Glycogen occupies the space around the nucleus in both the endothelial and smooth muscle cells.

In the present study, endothelial lining UVs demonstrated wide areas of damage and destruction with frequent patches of denuded endothelium. At these sites of endothelial loss, the basement membrane could not be visualized using PAS stain. Endothelial injury and damage was most observed at the $16^{\text {th }}$ gestational week. Stehbens et al. ${ }^{[10]}$ in their histological study of human UVs observed cell debris in the walls of umbilical vessels that could be attributed to hemodynamic stress of the fetoplacental circulation resembling early events of atherogenesis. Lu and Kassab, ${ }^{[15]}$ stated that the vascular walls are subjected to three hemodynamic forces; the blood pressure created by cardiac contraction, the circumferential stretch of the vessel with the cardiac cycle, and the shear stress. Shear stress is the frictional force of the viscous blood on the endothelial surface. One of the main functions of the vascular endothelium is to sense shear caused by the intraluminal blood flow ${ }^{[16]}$. According to Paszkowiak ${ }^{[17]}$ Shear stress is a force having both magnitude and direction. The magnitude is directly proportional to blood flow and fluid viscosity and indirectly proportional to vessel radius. Consequently, blood vessels with high flow and small lumens are exposed to high shear stress, while vessels with low flow and large diameters are exposed to low shear stress. Endothelial cells are exposed to shear stress in a pulsatile fashion correlating with the cardiac cycle. Noteworthy, the sustained laminar shear stress in a physiological range activates signaling pathways that induce the expression of atheroprotective and antithrombogenic genes encoding products that serve antioxidant, anti-inflammatory, anticoagulant, and antiapoptotic functions ${ }^{[18]}$. However, disturbed blood flow with low and reciprocating shear stress results in endothelial-dysfunction resembled atherogenesis. According to Struijk et al., ${ }^{[4]}$ the umbilical vessels are part of the fetal (fetoplacental) circulation which encompasses all blood vessels carrying fetal blood. The fetal heart builds up the fetal blood pressure to drive its blood through the fetal circulation. Blood pressure decreases as it passes through; the long umbilical vessels and then the placenta. Placental vascular bed is regarded as a low-resistance circulation which is a criterion essential for successful pregnancy outcome.

In the present work, adherence of inflammatory cells to denuded endothelial surface was observed particularly at the $13^{\text {th }}$ and $16^{\text {th }}$ weeks of gestation. This response is secondary to endothelial injury as a result of shear stress simulating events occurring in atherosclerotic lesions. Vascular endothelial cells mediate inflammatory responses secondary to their injury via surface expression of chemotactic and adhesion molecules and release of chemokines and cytokines. Molecules that stimulate leukocyte adhesion and migration are; vascular cell 
adhesion molecule 1 (VCAM-1), intercellular adhesion molecule 1 (ICAM-1) and monocyte chemotactic protein 1 (MCP1) ${ }^{[15,17,19]}$. Recent studies indicate that disturbed blood flow and associated low and reciprocating shear stress induce a sustained activation of some atherogenic genes in endothelial cells like monocyte chemotactic protein-1 (MCP-1) that induces monocyte infiltration into the arterial wall ${ }^{[18]}$.

In the present work, neointimal hyperplasia was observed in localized patches in umbilical vessel wall at the $16^{\text {th }}$. week of gestation while it progressed to welldeveloped complete layer at 20 weeks of gestation

Neointimal hyperplasia is a process recorded in normal physiology and in pathophysiological states. It is implicated in the pathogenesis of vascular occlusive diseases like; atherosclerosis and restenosis as in bypass graft and stenting as the result of chronic exposure to pathological levels of shear stress. It has been shown to be stimulated by low levels of shear stress and inhibited by high shear stress levels in vivo. This process involves proliferation and migration of smooth muscle cells from media towards the intima to replace endothelial cells by process of endothelial-mesenchymal transition. Associated expression of endothelial cell-surface molecules that stimulate leukocyte adhesion and migration occurs ${ }^{[17-19]}$. Chiu \& Chien, ${ }^{[18]}$ believe that, neointimal hyperplasia (Flow-induced arterial remodeling) is a compensatory arterial response to changes in shear stress that aims at maintaining mean shear stress of the arterial system and hence vascular homeostasis.

We speculate that migrating SMCs that constituted the neointima originated from different sources according to the gestational-age. At the $20^{\text {th }}$ week migrating SMCs mostly originated from the media. As proof-of-concept; first localization of migrating cells in stained sections at the media which was well-developed and thick at this stage as proved by morphometry. Second, SMCs of the neointima revealed negative immune staining for alpha smooth muscle actin denoting lack of contractile function. According to Lacolley et al. ${ }^{[20]}$ neointima is mainly constituted by vascular SMCs of subjacent media. These SMCs partially lose their contractile phenotype and acquire a synthetic one during their migration and intimal proliferation. The negative immune staining for laminin antibody was another evidence for immaturity and lack of contractility in SMCs of intimal proliferation at the $20^{\text {th }}$. week obtained in our study. Since laminins are the major basement membrane component responsible for signal transduction that control cell migration, survival, proliferation and differentiation, their expression depends on the maturation state of cells ${ }^{[21]}$.

We hypothesize that migrating cells at 13 weeks of gestation in the present work originated from cord blood stem cells or from Wharton's jelly based on the following evidences. Morphologically mesenchymal stem cells were seen among endothelial cells of intima in examined sections. These cells revealed positive immune reaction for $\alpha$-smooth muscle actin, a marker of mesenchymal stem cells. Additionally, it is well known that the umbilical cord blood contains haematopoietic stem cells (cord blood stem cells) and endothelial precursor cells (cord blood tissue cells) ${ }^{[22]}$. Moreover, mesenchymal cells can acquire endothelial-like phenotype through mesenchymal-endothelial transition ${ }^{[23]}$. This transition process is characterized by loss of cell-cell adhesions and changes in cell polarity. Endothelial cell markers, such as VE cadherin and PECAM-1 are reduced, while the expression of mesenchymal cell markers, such as a-smooth muscle actin (aSMA) and calponin are induced.

In the present work, SMCs of the media illustrated immature features initially at the $13^{\text {th }}$ week of gestation. On the contrary, that at the $20^{\text {th }}$ gestational week revealed mature characters. poor-developed features were manifested by pale H\&E acidophilic cytoplasmic staining, pale staining of basement membrane and cytoplasm by PAS stain, weak immunostaining for $\alpha$-smooth muscle actin and laminin. In addition to lack of collagen fibers in the extracellular matrix of vessel wall. Vascular SMCs the main stromal cells of vascular wall assume structural and physiological functions. It synthesizes the extracellular matrix during development and provide arterial wall with the capacity of withstanding high pressure of circulating blood ${ }^{[10,20]}$. In addition, the vascular SMCs possess fibroblastic function producing collagen and elastin in the developing media hence collagen content in the vessel wall is a reflection of SMC maturity ${ }^{[8]}$.

In the present work, the adventitia of UVs was replaced by Wharton's jelly. A significant increase in cord diameter, as proved by morphometry, with associated increase in amount of Wharton's jelly was seen at the $20^{\text {th }}$ week. Majority of its cells acquired fusiform (fibroblast-like) appearance and was crowded particularly close to UVs walls. These cells attained positive immune reaction for $\alpha$-smooth muscle actin. Besides, the spindle-shape cells of Wharton's jelly concentrate between and around umbilical arteries to transform and contribute to medial musculature ${ }^{[10]}$. Hinz et al., ${ }^{[21]}$ stated that the expression of $\alpha$-smooth muscle actin (the actin isoform typical of vascular SMCs) is the main characteristic feature of myofibroblast which are mesenchymal cells with both fibrogenesis and contractile functions.

\section{CONCLUSION}

The microstructure of early developing human umbilical vessels revealed development of umbilical vessels in the second trimester of pregnancy as a result of continuous remodeling process similar to that in pathological proliferative vascular diseases. This remodeling was initiated by secreted endothelial factors that influenced; smooth muscle cells of the media, stem cells circulating in cord blood and Wharton's jelly. 


\section{RECOMMENDATIONS}

Conducting comparative studies on the structure of human umbilical vessels at these early stages of their development in cases of complicated pregnancies might add knowledge to elucidate pathogenesis of these conditions.

\section{CONFLICT OF INTEREST}

There are no conflicts of interest.

\section{FUNDING}

This research did not receive any specific grant from any funding agency.

\section{REFERENCES}

1. Kinare A. Fetal environment. Indian J Radiol Imaging 2008; Nov;18(4):326- 44

2. Sadler, T W (Thomas W); Langman, Jan. Medical embryology. $12^{\text {th }}$ ed. / T.W. Sadler. Philadelphia: Wolters Kluwer Health/Lippincott Williams \& Wilkins, 2012. pp. $103-110$.

3. Wang Y, Zhao S. San Rafael (CA): Morgan \& Claypool Life Sciences; 2010. Integrated Systems Physiology: from Molecules to Function to Disease.

4. Struijk PC, Mathews VJ, Loupas T, Stewart PA, Clark E B, Steegers EAP, Wladimiroff JW. "Blood pressure estimation in the human fetal descending aorta". Ultrasound in Obstetrics and Gynecology 2008; 32 (5): 673681-. doi:10.1002/uog.6137. PMID 18816497.

5. Md Rafiqul Alam, Md Abdul Momen, Anjuman Ara Sultana, SM Nurul Hassan. Gross and Histomorphologic Study of the Umbilical Cord in Pre-gestational Diabetes Mellitus and Gestational Diabetes Mellitus. Bangladesh J. Anat. 2014; 12(1): $25-29$.

6. FillizAA, Rahime B, Keskin HL, Esra AK. Positive correlation between the quantity of Wharton's jelly in the umbilical cord and birth weight. Taiwan $\mathbf{J}$ Obstet Gynecol 2011 Mar;50(1):33- 6.

7. Kerdjoudj H, Berthelemy N, Rinckenbach S, Kearney-Schwartz A, Montagne K, Schaaf P, Lacolley P, Stoltz JF, Voegel JC, Menu P. Small vessel replacement by human umbilical arteries with polyelectrolyte film-treated arteries: in vivo behavior. J Am Coll Cardiol 2008 Nov 4;52(19):1589 -97.
8. Li WC, Zhang HM, Wang PJ, Xi GM, Wang HQ, Chen Y, Deng ZH, Zhang ZH, Huang TZ. Quantitative analysis of the microstructure of human umbilical vein for assessing feasibility as vessel substitute. Ann Vasc Surg 2008 MayJun;22(3):417- 24.

9. Gebrane-Younes J, Hoang NM, Orcel L. Ultrastructure of human umbilical vessels: a possible role in amniotic fluid formation? Placenta 1986 Mar-Apr;7(2):173 -85.

10. Stehbens WE, Wakefield JS, Gilbert-Barness E, Zuccollo JM. Histopathology and ultrastructure of human umbilical blood vessels. Fetal Pediatr Pathol 2005 Nov-Dec;24(6):297- 315.

11. Sexton AJ, Turmaine M, Cai WQ, Burnstock G. A study of the ultrastructure of developing human umbilical vessels. J Anat 1996 Feb;188 ( Pt 1):75- 85.

12. Bancroft JD, Gamble M. Marsland, Glees and Erikson's techniques. In: Bancroft JD, Gamble M, editors. Theory and practice of histological techniques. 5th ed. Belluno: Churchill Livingstone; 2002. pp. 104-106.

13. Fawcett DW, Jensh RP. Bloom and Fawcett: concise histology. $2^{\text {nd }}$ ed. New York: Hodder Arnold Publication; 2002.

14. Kumar P, Clark M. Clinical medicine. 5th ed. International Student Edition. Philadelphia, PA: Elsevier Saunders Limited; 2003. pp. 590-595.

15. Lu D, Kassab GS. Role of shear stress and stretch in vascular mechanobiology. J R Soc Interface. 2011 Oct 7;8(63):13791385-. doi: 10.1098/ rsif.2011.0177. Epub 2011 Jul 6.

16. Yousif LF, Di Russo J, Sorokin L. Laminin isoforms in endothelial and perivascular basement membranes. Cell Adh Migr 2013 JanFeb;7(1):101110-. doi: 10.4161/cam.22680. Epub 2012 Dec 21.

17. Paszkowiak JJ, Dardik A. Arterial wall shear stress: observations from the bench to the bedside. Vasc Endovascular Surg. 2003 Jan-Feb;37(1):47 -57

18. Chiu JJ, Chien S. Effects of disturbed flow on vascular endothelium: pathophysiological basis and clinical perspectives. Physiol Rev. 2011 Jan;91(1):327387-. doi: 10.1152/ physrev.00047.2009. 
19. Davies PF, Spaan JA, Krams R. Shear stress biology of the endothelium. Ann Biomed Eng. 2005 Dec;33(12):1714 -8.

20. Lacolley P, Regnault V, Nicoletti A, Li Z, Michel JB. The vascular smooth muscle cell in arterial pathology: a cell that can take on multiple roles. Cardiovasc Res. 2012 Jul 15;95(2):194204-. doi: 10.1093/cvr/cvs135. Epub 2012 Mar 31.

21. Hinz B, Celetta G, Tomasek JJ, Gabbiani G, Chaponnier C. Alpha smooth muscle actin expression upregulates fibroblast contractile activity. Mol Biol Cell. 2001 Sep;12(9):2730 -41.

22. Weiss ML, Troyer DL. Stem cells in the umbilical cord. Stem Cell Rev. 2006;2(2):155- 62.

23. Moonen JR, Lee ES, Schmidt M, Maleszewska M, Koerts JA, Brouwer LA, van Kooten TG, van Luyn MJ, Zeebregts CJ, Krenning G, Harmsen MC. Endothelial-to-mesenchymal transition contributes to fibro-proliferative vascular disease and is modulated by fluid shear stress. Cardiovasc Res. 2015 Dec 1;108(3):37786-. doi: 10.1093/cvr/ cvv175. Epub 2015 Jun 17. 


\title{
الملغص العربى \\ تظور اوعية الحبل السري الاموية في الانسان خلال الثلث الثاني من الحمل : دراسة نسيجية, مناعية هنتوكيميائية, و مورفومترية الانية
}

\author{
نجوي ابراهيم امين النفياوي \\ قسم التشريح و الاجنة ـ كلية الطب - جامعة عين شمس الفئ
}

المقدمة: الوظيفة الرئيسية للحبل السري هي تهيئة بيئة جيدة لنمو الجنين لضمان مولود بصحة جيدة. هنالك العديد من الابحاث

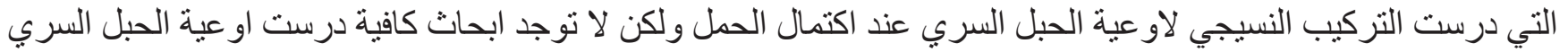

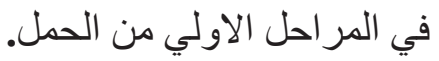
الهذف من البحث: هو در اسة تطور التركيب النسيجي الدقيق لاو عية الحبل السري في التلث الثاني من الحمل و بالتحديد في

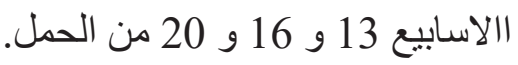

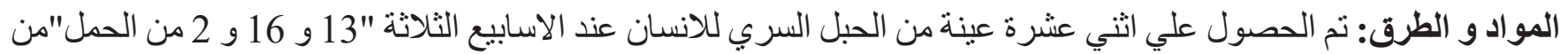

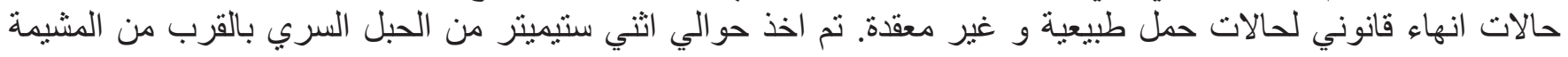
لتمرير ها الي بلوكات بار افين ثم تقطيعها و صبغها بالات بالصبغات التالية:

.haematoxylin and eosin, Masson Trichrome, Mallory trichrome, Orcein, \& Periodic Acid Schiff كذللك تم استخدام شر ائح البار افين لعمل صبغة مناعية هستوكيميائية بالاجسام المضادة التالية: alpha smooth muscle actin and laminin

ثم تم استخدام الثر ائح المصبو غة لعمل قياسات مورفومترية باستخدام بر امج التحليل الاكترونية.

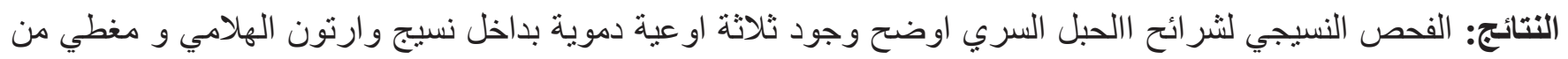

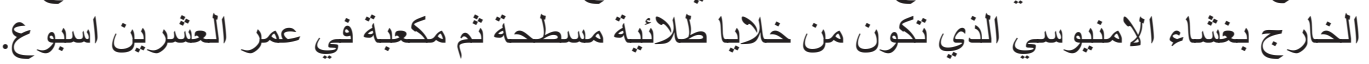

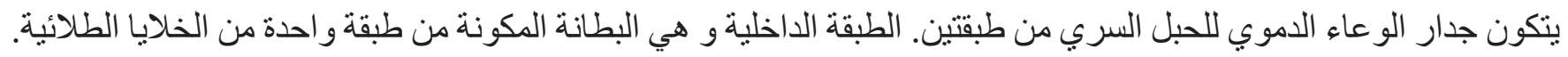

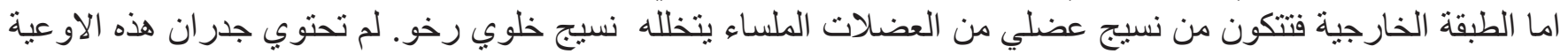

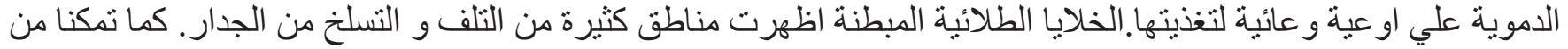

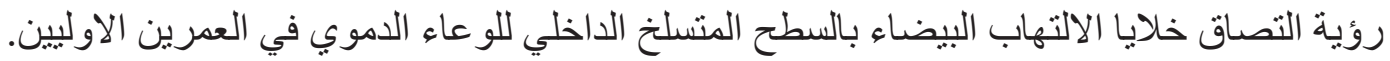

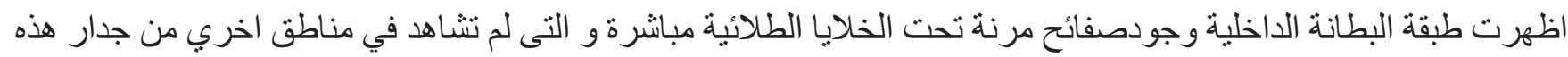

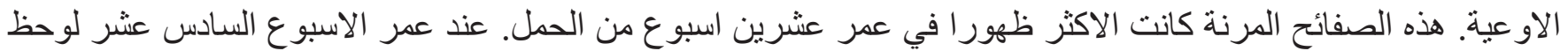

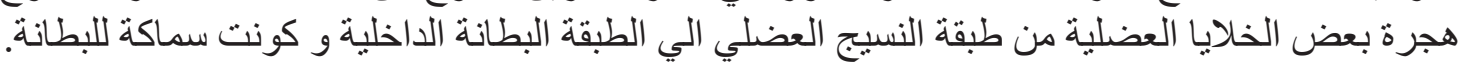

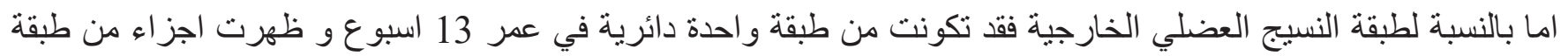

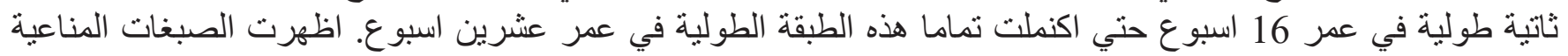

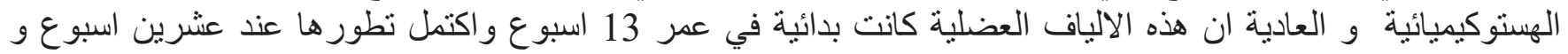
ذللك للطبقة الخارجية الدائرية من العضلات بالاتية الاساس اما الطبقة الداخلية فكانت اقل تطور ا في الاعمار الثثلاثة. لم تظهر الياف

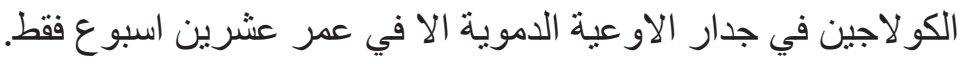

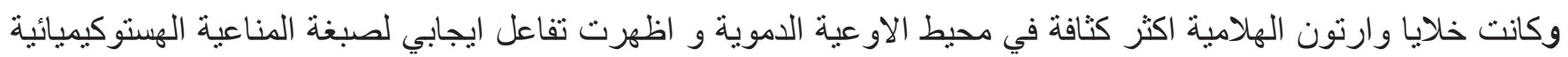
للخلايا الجذعية. وكانت أوردة الحبل السري ذات تجويف أوسع من الثر ايين. وزاد محيط الحبل السري عبر الاعمار الثلاثة . 
الخلاصة: اوضحت نتائج هذه الدر اسة حدوث تطور فى التركيب المجهري الدقيق لاو عية الحبل السري للانسان في الثلث الثناني

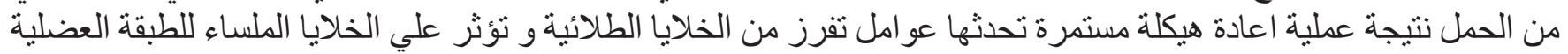

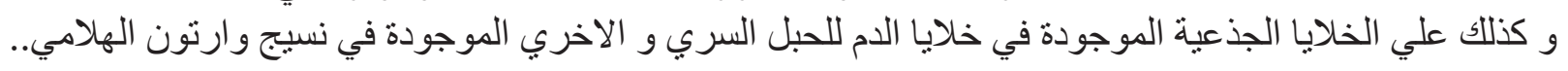

